\title{
Impact of mycoinsecticides and abamectin applications on species diversity and abundance of aquatic insects in rice fields of freshwater swamps of South Sumatra, Indonesia
}

\author{
SITI HERLINDA ${ }^{1,2, \vartheta}$, MONICA ALESIA ${ }^{3}$, SUSILAWATI ${ }^{2,4}$, CHANDRA IRSAN $^{1,2}$, HASBI $^{2,5}$, SUPARMAN $^{1,2}$, \\ ERISE ANGGRAINI ${ }^{1,2}$, ARSI ${ }^{1,2}$ \\ ${ }^{1}$ Department of Plant Pests and Diseases, Faculty of Agriculture, Universitas Sriwijaya. Jl. Raya Palembang-Prabumulih Km 32, Indralaya, Ogan Ilir \\ 30662, South Sumatra, Indonesia. Tel.: +62-711-580663, Fax.: +62-711-580276, "email: sitiherlinda@unsri.ac.id \\ ${ }^{2}$ Research Center for Sub-optimal Lands (PUR-PLSO), Universitas Sriwijaya. J1. Padang Selasa No. 524, Bukit Besar, Palembang 30139, South Sumatra, \\ Indonesia \\ ${ }^{3}$ Graduate Program of Crop Sciences, Faculty of Agriculture, Universitas Sriwijaya. Jl. Padang Selasa No. 524, Bukit Besar, Palembang 30139, South \\ Sumatra, Indonesia \\ ${ }^{4}$ Program of Agronomy, Faculty of Agriculture, Universitas Sriwijaya. Jl. Raya Palembang-Prabumulih Km 32, Indralaya, Ogan Ilir 30662, South \\ Sumatra, Indonesia \\ ${ }^{5}$ Program of Agricultural Engineering, Faculty of Agriculture, Universitas Sriwijaya. Jl. Raya Palembang-Prabumulih Km 32, Indralaya, Ogan Ilir \\ 30662, South Sumatra, Indonesia
}

Manuscript received: 11 April 2020. Revision accepted: 15 June 2020.

\begin{abstract}
Herlinda S, Alesia M, Susilawati, Irsan C, Hasbi, Suparman, Anggraini E, Arsi. 2020. Impact of mycoinsecticides and abamectin applications on species diversity and abundance of aquatic insects in rice fields of freshwater swamps of South Sumatra, Indonesia. Biodiversitas 21:3076-3083. Aquatic insects in rice fields generally are predators of rice insect pests. The application of insecticides may reduce the abundance and species diversity of these predators. This study aimed to determine the impact of mycoinsecticides and abamectin application on species diversity and abundance of aquatic insects in rice fields. Mycoinsecticides were made from Beauveria bassiana s.l., Metarhizium anisopliae s.l. and Cordyceps militaris s.l. with carrier from shrimp shell flour compost extract, vegetable oil, and Tween ${ }^{\circledR}$. The treatments were the mycoinsecticides and abamectin. The results showed there were eight aquatic insects species obtained in this study, i.e. unidentified Dytiscidae, Micronecta sp., Mesovelia sp., Ranatra sp., Anisops sp., Microvelia sp., unidentified species of Veliidae, and Orthetrum sp. belong to 7 families (Dytiscidae, Corixidae, Mesoveliidae, Nepidae, Notonectidae, Veliidae, Libellulidae), and three orders (Coleoptera, Hemiptera, and Odonata). All of the species were predatory insects. The application of mycoinsecticides did not reduce the abundance and species diversity of the aquatic predatory insects, but the application of abamectin reduced the abundance and species diversity of the predators. The highest insect species diversity was in the plots applied with $C$. militaris s.l., followed by the B. bassiana s.l. and M. anisopliae s.l. plots and the lowest one was found in the abamectin plot. So, the application of mycoinsecticides from B. bassiana s.l., M. anisopliae s.l. and C. militaris s.l. is safe for the aquatic predatory insects and to control rice insect pests than that of abamectin.
\end{abstract}

Keywords: Beauveria bassiana, Cordyceps militaris, Metarhizium anisopliae, mycoinsecticides, aquatic predatory insects

\section{INTRODUCTION}

The agricultural potential of the swampy area in Indonesia approximately 39.6 Mha, and 11.9 Mha is located in Sumatra (Margono et al. 2014) which is generally dominated by freshwater swamps. A freshwater swamp is a wetland ecosystem that generally floods with river water or rain throughout the year. The duration of stagnant water depends on the typology of the land. Our observation over the past 7 years in Ogan Ilir District of South Sumatra, Indonesia showed that flooding in the deep freshwater swampy typology is almost all year-round (October to July), middle freshwater swamps from November to June, and embankment freshwater swamps or shallow freshwater swamps from November to April. Due to stagnant water, the smallholder farmers underutilize their lands and start to plant rice and vegetables approaching the dry season.
Crops cultivated in various typologies of freshwater swamps vary depending on their adaptation to stagnant water. Rice is the most planted in freshwater swamps in South Sumatra (Lakitan et al. 2018a, b; Prabawati et al. 2019). Besides rice, chilies (Johari et al. 2014, 2016), bitter melon, long beans, eggplants, pumpkins, and cucumbers are also cultivated (Siaga et al. 2019). Rice is generally planted once a year (Hanif et al. 2020). Currently, some farmers earn $>100$ ha land who start planting rice two to three times a year, and several smallholder farmers grow rice two times a year by utilizing the remaining ratoons of the previous season's rice harvest (Lakitan et al. 2018b; Prabawati et al. 2019).

Intensive rice cultivation in freshwater swamps will increase the use of insecticides due to the increasing insect population (Prabawati et al. 2019). Commonly used insecticides are synthetic insecticides (Hanif et al. 2020) and sometimes bioinsecticides (Karenina et al. 2019; Prabawati et al. 2019; Hanif et al. 2020). Commonly 
insecticide used in rice fields in Indonesia is abamectin (Luo et al. 2013). Entomopathogenic fungi such as Beauveria bassiana (Ascomycota: Hypocreales) and Metarhizium anisopliae (Ascomycota: Hypocreales) are the most commonly used bioinsecticides (Prabawati et al. 2019). B. bassiana and M. anisopliae are widely used because they are easily found in freshwater swamps (Herlinda et al. 2018b; Safitri et al. 2018; Gustianingtyas et al. 2020). and able to kill important insect pests such as brown planthopper, Nilaparvata lugens (Homoptera: Delphacidae) (Sumikarsih et al. 2019) and Spodoptera litura (Lepidoptera: Noctuidae) (Ayudya et al. 2019). Although the entomopathogenic fungi are generally reported to be host-specific (Hanif et al. 2020), it is necessary to monitor the impact of these mycoinsecticides on the abundance of beneficial arthropods.

The impact of synthetic insecticide applications on beneficial arthropods has been widely studied (Azod et al. 2016; Khan et al. 2018). However, there is not much information on the impact of synthetic insecticide and mycoinsecticides application on aquatic insects. Aquatic insects in the rice field are generally dominated by predatory insects (Thirumalai et al. 2002). The abundance and diversity of the beneficial aquatic insect species in the rice field are high (Settle et al. 1996; Herlinda et al. 2019a,b). The commonly found of the aquatic insects were Microvelia douglasi, Mesovelia vittigera, Anisops barbatus, Ranatra elongata, and Micronecta scutellaris (Thirumalai et al. 2002). These aquatic insects play an important role in the aquatic ecosystem (Dunbar et al. 2010) as natural enemies of rice insect pests (Heong et al. 2009).

The B. bassiana, M. anisopliae and Cordyceps militaris (Ascomycota: Cordycipitaceae) do not reduce abundance and species diversity of canopy predatory arthropods in the rice field (Prabawati et al. 2019), but the effect of the fungi on the species diversity and abundance of aquatic insects has not been studied. The intensive application of insecticides and mycoinsecticides may have an impact on the abundance and species diversity of the aquatic insects. The high abundance and species diversity of arthropod in water is an indicator of healthy aquatic ecosystems (Salachna and Olearczyk 2020). This study aimed to determine the effect of the mycoinsecticides application of B. bassiana, M. anisopliae, and C. militaris and abamectin on the species diversity and abundance of aquatic insects in the rice field.

\section{MATERIALS AND METHODS}

\section{Study area}

The field experiment was carried out in the center of the freshwater swampy rice field in the Pelabuhan Dalam Village of Pemulutan Subdistrict, Ogan Ilir District of South Sumatra Province. The area of freshwater rice fields in the study site was more than 800 ha. The experimental plot covers 1 ha of the freshwater swampy rice field that divided into 12 subplots for 4 treatments, each treatment has 3 replicates. This study uses a Randomized Block Design. Field trials were conducted from May to August
2018 and continued with the identification of collected aquatic insects until December 2018. The four treatments used in this study were the application of mycoinsecticides derived from B. bassiana, M. anisopliae, C. militaris, and abamectin as a positive control. B. bassiana s.l. (BPCmS isolate) and M. anisopliae s.l. (MSwTp1 isolate) were used in this study from the exploration in the South Sumatra (Indonesia) soil by Safitri et al. (2018), while C. militaris s.l. (CmKT isolate) was collected from Central Kalimantan. The identification of three entomopathogenic fungal species used in this experiment was carried out by Dr. Suwandi (a mycologist from Universitas Sriwijaya). The fungi were identified based on microscopic and macroscopic characteristics.

\section{Preparation of land and rice planting}

Rice cultivation was carried out through the stages of tillage, seed preparation, planting, and maintenance as carried out by local farmers. Soil processing was carried out using a singkal plow machine and then smoothed using a hoe added running water so the soil becomes muddy. After the soil was cultivated, the rice was grown and added with a dose of 1 ton $\mathrm{ha}^{-1}$ manure and flooded with water for 14 days before planting.

Seed sowing by local farmers includes seed treatment, seed curing, and seed sowing. The seeds used were certified Mekongga variety at a dose of $50 \mathrm{~kg} \mathrm{ha}^{-1}$. The seeds were soaked for 24 hours with shrimp shell flour compost at a dose of $0.5 \mathrm{~mL} \mathrm{~L}{ }^{-1}$. Composting of shrimp shell flour was made according to the method of Suwandi et al. (2012). To facilitate germination after 24 hours soaking, broadcast the seeds in moist conditions on the rice field dike that has been coated with rice mud and moist manure. The seeds were broadcast by sprinkling called Samir.

Insecticides used in this study were mycoinsecticides and abamectin, while weeding was done mechanically without using herbicides. Watering was done by using a pump, and manure was used as fertilizer. Shrimp shell flour compost extract at a dose of $2 \mathrm{~L} \mathrm{ha}^{-1}$ was applied every 2 weeks until the milky stage (milk-cooked phase) by spraying to increase soil fertility. Rice was planted using a legowo row of 2: 1 planting system with a spacing of $12.5 \times 50 \times 50 \mathrm{~cm}^{3}$. It was conducted by transplantation using 7-10 days old seedlings. Seedlings were transplanted with a maximum water level of half of rice seedlings height. The higher the rice plants, the more water was pumped into the fields. The plants were watered daily to accommodate and maintain the presence of aquatic insects inhabiting the rice field water. The rice field was inundated until nearing the ripe phase of milk and after the grains of rice were at the ripening stage, the fields began to be dried and the experiment was stopped.

\section{Production and application of mycoinsecticides and abamectin}

Mycoinsectides used as treatments in this study were derived from 3 species of entomopathogenic fungi, i.e. $B$. bassiana s.l., $M$. anisopliae s.l. and $C$. militaris s.l. and commercial insecticides abamectin as a positive control. Production of mycoinsecticides was following the modified 
method of Mascarin et al. (2015). Entomopathogenic fungi were cultured on Sabouraud Dextrose Agar (SDA, Merck) solid media and incubated for 10 days at room temperature. Entomopathogenic fungi grew on solid media were transferred into Sabouraud Dextrose Broth (SDB, Merck) liquid media and incubated for 7 days under agitation at $120 \mathrm{rpm}$. Liquid fungal culture with a minimum density of $1 \times 10^{9}$ conidia $\mathrm{mL}^{-1}$ was used as the active ingredient of mycoinsecticides. The mycoinsecticides were made from a mixture of $600 \mathrm{~mL}$ of liquid entomopathogenic fungal culture, $400 \mathrm{~mL}$ carrier made from shrimp shell flour compost extract, $10 \mathrm{~mL}$ vegetable oil, and $10 \mathrm{~mL}$ of a sterile aqueous solution of $0.04 \%$ polyoxyethyl-189 ene sorbitan mono-oleate (Tween $®)$. Mycoinsectides were applied at a dose of $2 \mathrm{~L} \mathrm{ha}^{-1}$ every two weeks, starting on the $14^{\text {th }}, 28^{\text {th }}, 42^{\text {nd }}$, and $56^{\text {th }}$ days after transplanting (DAT), while abamectin was applied according to the manufacturer's instructions with the same spraying schedule with the mycoinsecticides.

\section{Samplings of aquatic insects}

One day after mycoinsecticides and abamectin were sprayed on the rice field, the sampling of aquatic insects was carried out, which were on the $15^{\text {th }}, 29^{\text {th }}, 43^{\text {rd }}$, and $57^{\text {th }}$ DAT, i.e. $2^{\text {nd }}$ of June $2018,16^{\text {th }}$ June 2018 , $30^{\text {th }}$ June 2018 , and $17^{\text {th }}$ July 2018 , while the next sampling was not carried out because the rice fields began to dry out. The sampling of aquatic insects following the method of Salmah et al. (2017) by using a fishnet $(0.4 \mathrm{~mm}$ mesh) conducted at 6.00-7.00 a.m.

Sampling was carried out by swinging the net into rice field water with a $2 \times 2 \mathrm{~m}^{2}$ sampling area for each treatment and repeated three times. The obtained insects were put into a vial containing $96 \%$ ethanol and then taken to the laboratory for identification. The taxonomic identification of aquatic insects using morphological features based on Basu et al. (2016) and Miller and Bergsten (2016) up to the genus level.

\section{Statistical analyses}

Data on the number of each species were used to calculate species abundance and diversity. The obtained data on species abundance were subjected to Analysis of variance (ANOVA) followed by Tukey's Honestly Significant Different (HSD) to determine significant differences among treatments at a level of $5 \%$ using the software program of SAS University Edition 2.7 9.4 M5. Analysis of the species diversity was carried out using the Shannon index $\left(\mathrm{H}^{\prime}\right)$. The diversity level was also evaluated by the Evenness index $\left(\mathrm{J}^{\prime}\right)$ derived from the Shannon function and Berger-Parker dominance biodiversity indices.

\section{RESULTS AND DISCUSSION}

\section{Aquatic insect species}

This study successfully collected 8 species of aquatic insects from all experimental plots, namely unidentified species of Dytiscidae, Micronecta sp., Mesovelia sp., Ranatra sp., Anisops sp., Microvelia sp., unidentified species of Veliidae, Orthetrum sp. (Figure 1) belong to 7 families (Dytiscidae, Corixidae, Mesoveliidae, Nepidae, Notonectidae, Veliidae, Libellulidae), 3 orders (Coleoptera, Hemiptera, and Odonata), (Table 1). The number of species found in the plot applied with B. bassiana s.l. was 6 species (unidentified species of Dytiscidae, Micronecta sp., Mesovelia sp., Anisops sp., Microvelia sp., and Orthetrum sp.) and in the plot applied with $M$. anisopliae s.l. were 6 species (unidentified species of Dytiscidae, Micronecta sp., Mesovelia sp., Microvelia sp., unidentified species of Veliidae, and Orthetrum sp.). In the plot applied with $C$. militaris s.l. were 7 species (unidentified species of Dytiscidae, Micronecta sp., Mesovelia sp., Anisops sp., Microvelia sp., unidentified species of Veliidae, and Orthetrum sp.). While in the abamectin plot there were only 5 species found (Mesovelia sp., Ranatra sp., Anisops sp., Microvelia sp. and Orthetrum sp.). In total, eight aquatic insect species were collected, all of the species were predators of rice insect pests.

\section{Abundance and diversity of aquatic insect species}

The abundance of aquatic insects tends to increase in plots applied with the mycoinsecticides (B. bassiana, $M$. anisopliae, and C. militaris s.1.), however, the abundance of the aquatic insect in the abamectin plot was not increased (Figure 2). The plots applied with $C$. militaris s.l. had the most abundant insects, while the plots applied with the abamectin had the lowest abundant insects. The abundance of each species was not significantly different, but in total, aquatic insect abundance was significantly different among treatments. The highest abundance of Micronecta sp. was in plot applied with $C$. militaris s.1. (37.67 individual $4 \mathrm{~m}^{-2}$ ) but significantly different from that of plots applied with $B$. bassiana (30.33 individual $\left.4 \mathrm{~m}^{-2}\right)$, M. anisopliae $(30.33$ individual $\left.4 \mathrm{~m}^{-2}\right)$ and abamectin $\left(0\right.$ individual $\left.4 \mathrm{~m}^{-2}\right)$ (Table 2 ). The plot applied with abamectin showed a significant decrease in Micronecta sp.

The aquatic insects collected in the mycoinsecticides plots applied were belonging to 3 orders (Coleoptera, Hemiptera, and Odonata), while in the abamectin plot there were only 2 orders of aquatic insects (Hemiptera, and Odonata) (Figure 3). The most dominant order in all plots was Hemiptera. Species composition in the plots applied with mycoinsecticides was different from the abamectin plots (Figure 4). The species composition in the three mycoinsecticide plots had the same tendency. Micronecta sp. was not found in the abamectin plots, but Micronecta sp. was the most dominant species in the plots applied with mycoinsecticides. The presence and composition of aquatic insect species can be used as an indicator of the water quality.

The results of the study showed that the diversity of aquatic insect species increased with increasing age of rice. The species diversity was higher in plots applied with mycoinsecticides than plots applied with abamectin (Table 3 ). The highest species diversity on the $15^{\text {th }}$ and $29^{\text {th }}$ DAT was in the plots applied with $C$. militaris s.l., followed by those applied with $B$. bassiana s.l. However, the highest species diversity on the $43^{\text {rd }}-57^{\text {th }}$ DAT was in the plots applied with $B$. bassiana. 


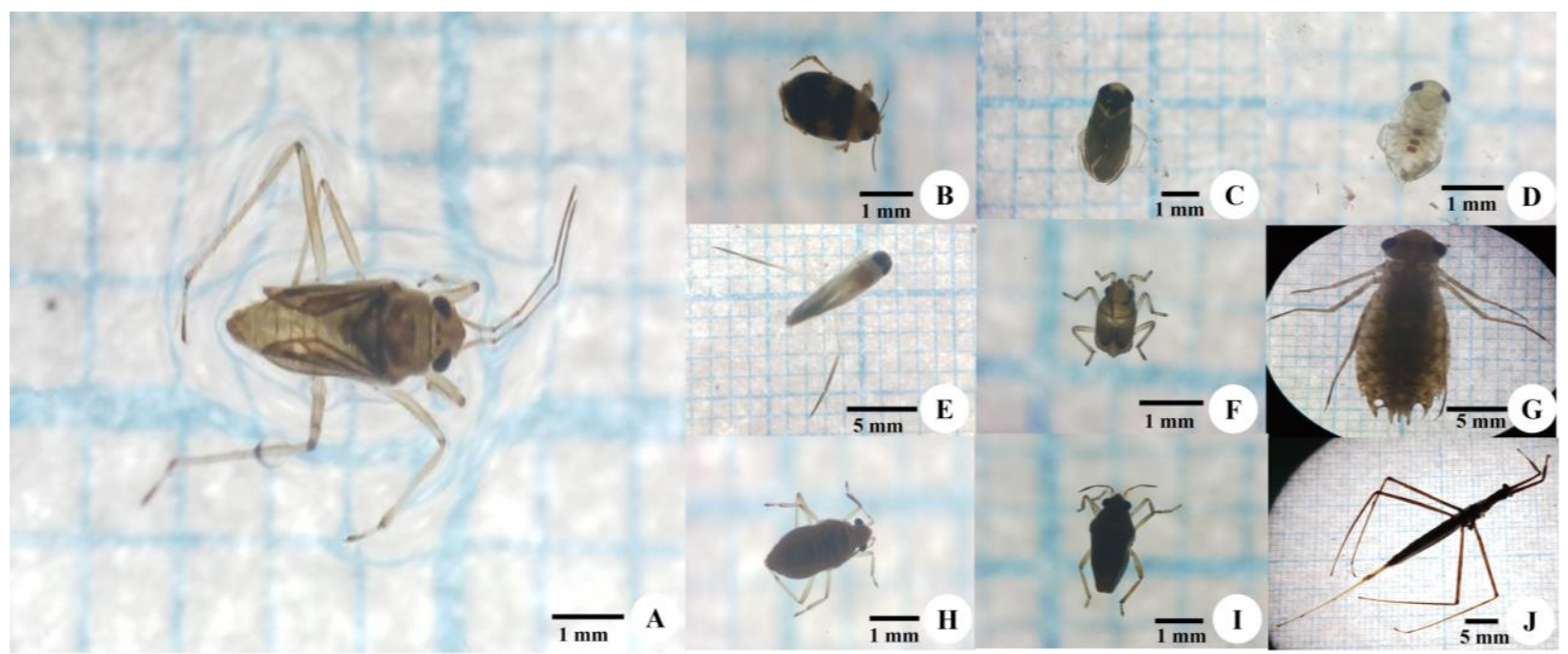

Figure 1. Aquatic insect species obtained in complete rice production cycle: A. Mesovelia sp., B. Unidentified species of Dytiscidae, C. Micronecta sp. adult, D. Micronecta sp. nymph, E. Anisops sp., F. Unidentified species of Veliidae, G. Orthetrum sp., H-I. Microvelia sp., J. Ranatra sp.

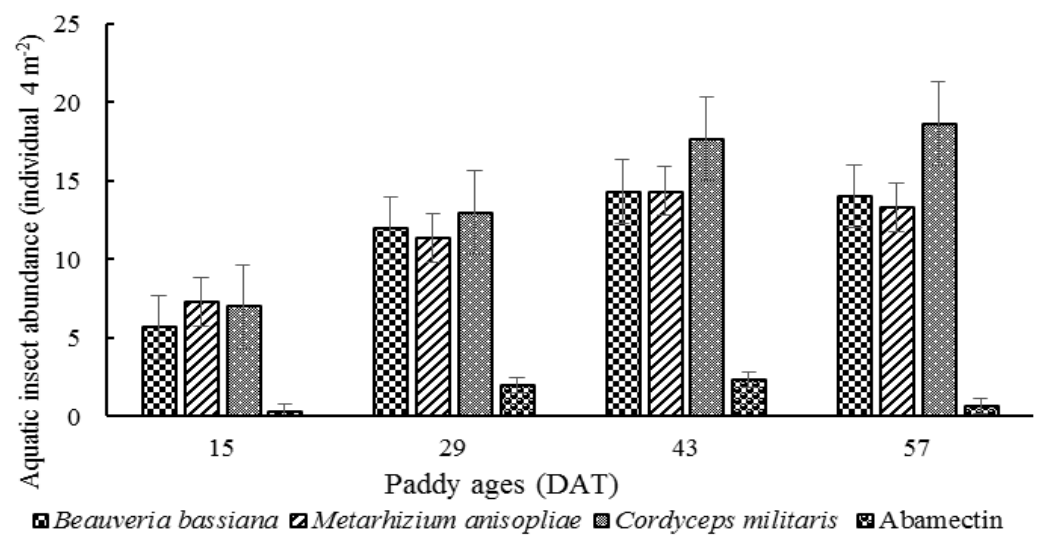

Figure 2. Aquatic insect abundance in rice field applied with mycoinsecticides of: A. Beauveria bassiana s.1., B. Metarhizium anisopliae s.1., C. Cordyceps militaris s.1., D. Abamectin
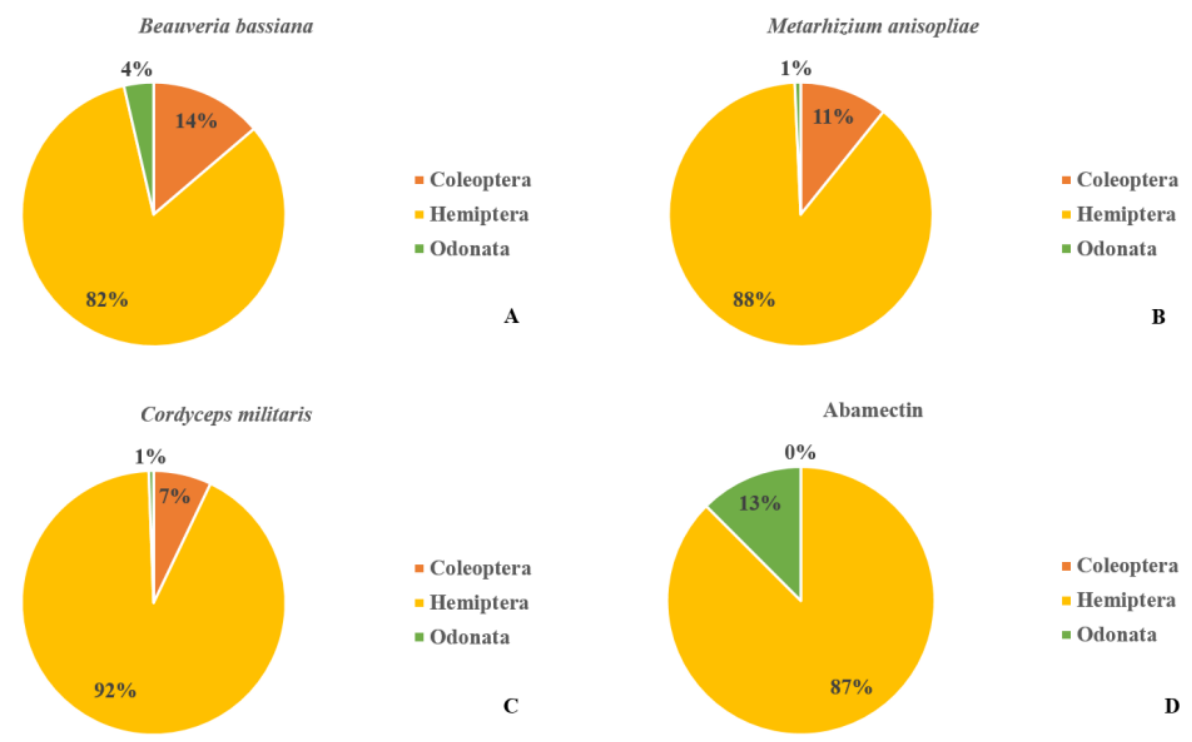

Figure 3. The relative abundance of the order of aquatic insect in rice field applied with mycoinsecticides of: A. Beauveria bassiana s.l., B. Metarhizium anisopliae s.1., C. Cordyceps militaris s.1., D. Abamectin 

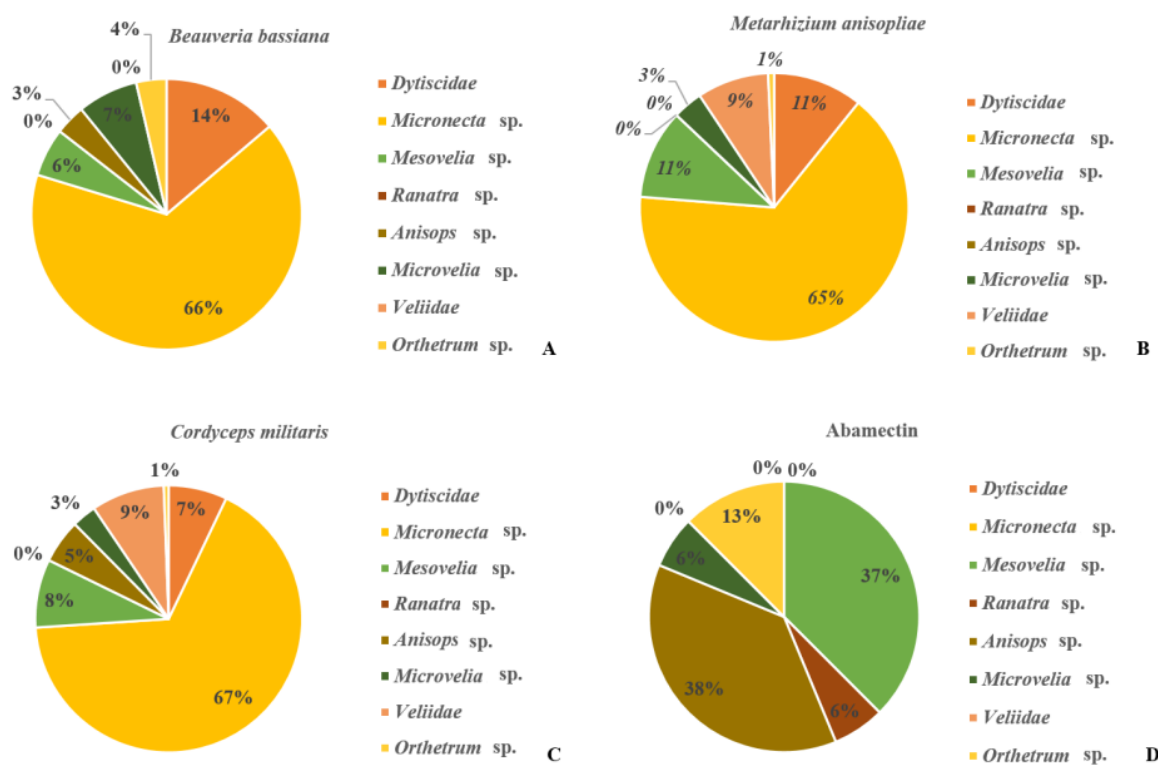

Figure 4. The relative abundance of aquatic insect species in rice field applied with mycoinsecticides of: A. Beauveria bassiana s.l., B. Metarhizium anisopliae s.1., C. Cordyceps militaris s.l., D. Abamectin

Table 1. Aquatic insect in rice field applied with mycoinsecticides of Beauveria bassiana s.1., Metarhizium anisopliae s.l. and Cordyceps militaris s.l. and abamectin

\begin{tabular}{|c|c|c|c|c|c|c|}
\hline \multirow[t]{2}{*}{ Order } & \multirow[t]{2}{*}{ Family } & \multirow[t]{2}{*}{ Species } & \multicolumn{4}{|c|}{ Insecticide treatment } \\
\hline & & & $\begin{array}{c}\text { Beauveria bassiana } \\
\text { s.l. }\end{array}$ & $\begin{array}{l}\text { Metarhizium } \\
\text { anisopliae } \text { s.l. }\end{array}$ & $\begin{array}{c}\text { Cordyceps militaris } \\
\text { s.l. }\end{array}$ & Abamectin \\
\hline Coleoptera & Dytiscidae & Unknown species & + & + & + & - \\
\hline \multirow[t]{6}{*}{ Hemiptera } & Corixidae & Micronecta sp. & + & + & + & - \\
\hline & Mesoveliidae & Mesovelia sp. & + & + & + & + \\
\hline & Nepidae & Ranatra sp. & - & - & - & + \\
\hline & Notonectidae & Anisops sp. & + & - & + & + \\
\hline & Veliidae & Microvelia sp. & + & + & + & + \\
\hline & & Unknown species & - & + & + & - \\
\hline Odonata & Libellulidae & Orthetrum sp. & + & + & + & + \\
\hline
\end{tabular}

Note: + insects found,-no insects found

\section{Discussion}

Eight aquatic insect species were obtained in the center of freshwater swamps from June $2^{\text {nd }}$ to July $17^{\text {th }}$. In the dried rice field after July 17 the aquatic insects were no longer found. However, in the rice fields that still inundated; the aquatic insects still could be found. Therefore, the presence of deep freshwater swamp is important for conserving aquatic insects in the dry season.

All species of aquatic insects collected in this study were predatory insects that attack rice insect pests. All species belonging to Dytiscidae (unidentified species) or diving beetles were predators of insects whose habitat is close to the water surface (Watanabe 2019) such as living on the stems and lower leaves and attacking the rice insect pests, such as Gryllotalpa orientalis (Ohba 2009). Micronecta sp. and Mesovelia sp. are predatory insects commonly found and suck out the internal body fluids of the rice insect pests (Wakhid et al. 2020). Ranatra sp. is predators that have a role in regulating the balance of insect populations of the rice insect pests (Thongphak and Iwai 2016). Anisops sp. is commonly found in rice field water in
Indonesia and also known as a predator for rice insect pests (Wakhid et al. 2020). Microvelia sp. and Veliidae (unidentified species) were reported as predators of brown planthoppers (Heong, 2009). Immature and adult stages of Orthetrum sp. prey on various insect species from various families (Salmah et al. 2017; Wakhid et al. 2020). The aquatic insects in rice fields obtained in this study generally attack rice insect pests that inhabit the base of the stem, such as brown planthopper ( $N$. lugens) (Heong 2009).

The results showed that the abundance of aquatic insects decreased significantly in the abamectin plot, but it remained high in all three plots applied with mycoinsecticides. Abamectin is an insecticide that is commonly applied in the rice field to control brown planthoppers in Indonesia. Abamectin is contact poison and stomach poison and widely chosen and applied by farmers in Indonesia because it has a broad spectrum that kills many species of insect pests (Luo et al. 2013). Abamectin that flows into the rice field water will poison and cause the death of aquatic insects. 
The abundance of aquatic insects in the three plots applied with mycoinsecticides from $B$. bassiana s.l., $M$. anisoplia s.l. and $C$. militaris s.l. remain high since these mycoinsecticides did not poison the aquatic insects. These three entomopathogenic fungal species have specific hosts, i.e. the order of Lepidoptera or Homoptera (Shrestha et al. 2012), while the aquatic insects obtained in this study belong to the orders of Hemiptera, Coleoptera, and Odonata. B. bassiana is effective in poisoning and killing S. litura (Lepidoptera) (Ayudya et al. 2019), and N. lugens (Homoptera) (Sumikarsih et al. 2019). M. anisoplia effectively attacks Lepidoptera (Ayudya et al. 2019), while C. militaris generally attacks insect pests of which attacks palm oil leaves (Lepidoptera) (Shrestha et al. 2012). Prabawati et al. (2019) reported that application of $B$. bassiana, $M$. anisoplia, and $C$. militaris in rice fields reduce insect pest population, but do not harm predatory arthropods inhabiting the canopy and rice soil surfaces. Therefore, the application of B. bassiana, M. anisopliae, and $C$. militaris in rice fields are beneficial in reducing rice insect pests and safe for the aquatic insect as predators of rice insect pests.

Table 2. The abundance of aquatic insect species in rice field applied with mycoinsecticides of Beauveria bassiana s.l., Metarhizium anisopliae s.l. and Cordyceps militaris s.l. and abamectin

\begin{tabular}{|c|c|c|c|c|c|c|c|c|}
\hline \multirow{2}{*}{$\begin{array}{c}\text { Rice } \\
\text { age } \\
\text { (DAT) }\end{array}$} & \multirow[b]{2}{*}{$\begin{array}{c}\text { Species of } \\
\text { aquatic insect }\end{array}$} & \multicolumn{4}{|c|}{ The abundance of aquatic insects (individual $4 \mathrm{~m}^{-2}$ ) } & \multirow[b]{2}{*}{ F value } & \multirow[b]{2}{*}{$P$ value } & \multirow[b]{2}{*}{$\begin{array}{l}\text { Tukey's } \\
\text { HSD test }\end{array}$} \\
\hline & & $\begin{array}{c}\text { Beauveria } \\
\text { bassiana } \text { s.l. }\end{array}$ & $\begin{array}{c}\text { Metarhizim } \\
\text { anisopliae s.l. }\end{array}$ & $\begin{array}{c}\text { Cordyceps } \\
\text { militaris s.l. }\end{array}$ & Abamectin & & & \\
\hline \multirow[t]{8}{*}{15 DAT } & Dytiscidae & 0.00 & 0.00 & 0.00 & 0.00 & - & - & - \\
\hline & Micronecta sp. & 5.33 & 6.33 & 5.67 & 0.00 & $0.25^{\mathrm{ns}}$ & 0.86 & - \\
\hline & Mesovelia sp. & 0.00 & 0.67 & 0.67 & 0.00 & $0.57^{\mathrm{ns}}$ & 0.65 & - \\
\hline & Ranatra sp. & 0.00 & 0.00 & 0.00 & 0.00 & - & - & - \\
\hline & Anisops sp. & 0.00 & 0.00 & 0.00 & 0.00 & - & - & - \\
\hline & Microvelia sp. & 0.00 & 0.00 & 0.67 & 0.33 & $0.62^{\mathrm{ns}}$ & 0.63 & - \\
\hline & Veliidae & 0.00 & 0.00 & 0.00 & 0.00 & - & - & - \\
\hline & Orthetrum sp. & 0.33 & 0.33 & 0.00 & 0.00 & $0.57^{\mathrm{ns}}$ & 0.65 & - \\
\hline \multirow[t]{8}{*}{29 DAT } & Dytiscidae & 0.00 & 0.00 & 0.00 & 0.00 & - & - & - \\
\hline & Micronecta sp. & 11.67 & 7.00 & 6.00 & 0.00 & $1.51^{\mathrm{ns}}$ & 0.30 & - \\
\hline & Mesovelia sp. & 0.00 & 4.33 & 4.00 & 2.00 & $0.41^{\mathrm{ns}}$ & 0.75 & - \\
\hline & Ranatra sp. & 0.00 & 0.00 & 0.00 & 0.00 & - & - & - \\
\hline & Anisops sp. & 0.00 & 0.00 & 3.00 & 0.00 & $1.00^{\mathrm{ns}}$ & 0.45 & - \\
\hline & Microvelia sp. & 0.00 & 0.00 & 0.00 & 0.00 & - & - & - \\
\hline & Veliidae & 0.00 & 0.00 & 0.00 & 0.00 & - & - & - \\
\hline & Orthetrum sp. & 0.33 & 0.00 & 0.00 & 0.00 & $1.00^{\mathrm{ns}}$ & 0.45 & - \\
\hline \multirow[t]{8}{*}{43 DAT } & Dytiscidae & 3.00 & 2.67 & 1.33 & 0.00 & $0.78^{\mathrm{ns}}$ & 0.55 & - \\
\hline & Micronecta sp. & 7.00 & 10.00 & 11.33 & 0.00 & $1.80^{\mathrm{ns}}$ & 0.25 & - \\
\hline & Mesovelia sp. & 0.00 & 0.00 & 0.00 & 0.00 & - & - & - \\
\hline & Ranatra sp. & 0.00 & 0.00 & 0.00 & 0.00 & - & - & - \\
\hline & Anisops sp. & 1.67 & 0.00 & 0.00 & 2.00 & $0.57^{\mathrm{ns}}$ & 0.65 & - \\
\hline & Microvelia sp. & 1.67 & 1.67 & 0.00 & 0.00 & $1.00^{\mathrm{ns}}$ & 0.45 & - \\
\hline & Veliidae & 0.00 & 0.00 & 5.00 & 0.00 & $1.00^{\mathrm{ns}}$ & 0.45 & - \\
\hline & Orthetrum sp. & $1.00^{c}$ & $0.00^{\mathrm{a}}$ & $0.00^{\mathrm{a}}$ & $0.33^{\mathrm{b}}$ & $8.00^{*}$ & 0.02 & 0.22 \\
\hline \multirow[t]{8}{*}{57 DAT } & Dytiscidae & 3.33 & 2.33 & 2.67 & 0.00 & $1.33^{\mathrm{ns}}$ & 0.35 & - \\
\hline & Micronecta sp. & 6.33 & 7.00 & 14.67 & 0.00 & $1.54^{\mathrm{ns}}$ & 0.30 & - \\
\hline & Mesovelia sp. & 2.67 & 0.00 & 0.00 & 0.00 & $1.00^{\mathrm{ns}}$ & 0.45 & - \\
\hline & Ranatra sp. & 0.00 & 0.00 & 0.00 & 0.33 & $1.00^{\mathrm{ns}}$ & 0.45 & - \\
\hline & Anisops sp. & 0.00 & 0.00 & 0.00 & 0.00 & - & - & - \\
\hline & Microvelia sp. & 1.67 & 0.00 & 1.00 & 0.00 & $0.59^{\mathrm{ns}}$ & 0.64 & - \\
\hline & Veliidae & 0.00 & 4.00 & 0.00 & 0.00 & $3.50^{\mathrm{ns}}$ & 0.09 & - \\
\hline & Orthetrum sp. & 0.00 & 0.00 & 0.33 & 0.33 & $0.57^{\mathrm{ns}}$ & 0.65 & - \\
\hline \multirow[t]{8}{*}{ Total } & Dytiscidae & 6.33 & 5.00 & 4.00 & 0.00 & $2.57^{\mathrm{ns}}$ & 0.15 & - \\
\hline & Micronecta sp. & $30.33^{\mathrm{b}}$ & $30.33^{\mathrm{b}}$ & $37.67^{c}$ & $0.00^{\mathrm{a}}$ & $13.91 *$ & 0.00 & 1.67 \\
\hline & Mesovelia sp. & 2.67 & 5.00 & 4.67 & 2.00 & $0.11^{\mathrm{ns}}$ & 0.95 & - \\
\hline & Ranatra sp. & 0.00 & 0.00 & 0.00 & 0.33 & $1.00^{\mathrm{ns}}$ & 0.45 & - \\
\hline & Anisops sp. & 1.67 & 0.00 & 3.00 & 2.00 & $0.27^{\mathrm{ns}}$ & 0.84 & - \\
\hline & Microvelia sp. & 3.34 & 1.67 & 1.67 & 0.33 & $0.88^{\mathrm{ns}}$ & 0.50 & - \\
\hline & Veliidae & 0.00 & 4.00 & 5.00 & 0.00 & $1.17^{\mathrm{ns}}$ & 0.40 & - \\
\hline & Orthetrum sp. & 1.66 & 0.33 & 0.33 & 0.66 & $2.60^{\mathrm{ns}}$ & 0.15 & - \\
\hline
\end{tabular}

Note: $\mathrm{ns}=$ not significantly different; $*$ = significantly different; values within a row followed by the same letters were not significantly different at $\mathrm{P}<0.05$ according to Tukey's HSD test. Original data were transformed using $\sqrt{ }\left(\mathrm{n}_{\mathrm{i}}+0.5\right)$ transformation before statistical analysis 
Table 3. Characteristics of aquatic insect communities in rice field applied with mycoinsecticides of Beauveria bassiana s.l., Metarhizium anisopliae s.l. and Cordyceps militaris s.l. and abamectin

\begin{tabular}{|c|c|c|c|c|c|}
\hline \multirow[b]{2}{*}{$\begin{array}{l}\text { Rice age } \\
\text { (DAT) }\end{array}$} & \multirow[b]{2}{*}{ Characteristics of communities } & \multicolumn{4}{|c|}{ Insecticides } \\
\hline & & $\begin{array}{c}\text { Beauveria } \\
\text { bassiana s.l. }\end{array}$ & $\begin{array}{l}\text { Metarhizium } \\
\text { anisopliae s.l. }\end{array}$ & $\begin{array}{l}\text { Cordyceps } \\
\text { militaris s.l. }\end{array}$ & Abamectin \\
\hline \multirow[t]{4}{*}{$15 \mathrm{DAT}$} & $\begin{array}{l}\text { Abundance of aquatic insect species }(\mathrm{N}) \\
\text { (individual } 4 \mathrm{~m}^{-2} \text { ) }\end{array}$ & 5.67 & 7.33 & 7.00 & 0.33 \\
\hline & Shanon wiener index $\left(\mathrm{H}^{\prime}\right)$ & 0.22 & 0.49 & 0.62 & 0.00 \\
\hline & Evennes index $(\mathrm{E})$ & 0.32 & 0.44 & 0.56 & 0.00 \\
\hline & Dominance index (D) & 0.94 & 0.86 & 0.81 & 1.00 \\
\hline \multirow[t]{4}{*}{29 DAT } & $\begin{array}{l}\text { Abundance of aquatic insect species }(\mathrm{N}) \\
\text { (individual } 4 \mathrm{~m}^{-2} \text { ) }\end{array}$ & 12.00 & 11.33 & 13.00 & 2.00 \\
\hline & Shanon wiener index $\left(\mathrm{H}^{\prime}\right)$ & 0.13 & 0.67 & 1.06 & 0.00 \\
\hline & Evennes index $(\mathrm{E})$ & 0.18 & 0.96 & 0.96 & 0.00 \\
\hline & Dominance index (D) & 0.97 & 0.62 & 0.46 & 1,00 \\
\hline \multirow[t]{4}{*}{$43 \mathrm{DAT}$} & $\begin{array}{l}\text { Abundance of aquatic insect species }(\mathrm{N}) \\
\text { (individual } 4 \mathrm{~m}^{-2} \text { ) }\end{array}$ & 14.33 & 14.33 & 17.67 & 2.33 \\
\hline & Shanon wiener index $\left(\mathrm{H}^{\prime}\right)$ & 1.36 & 0.81 & 0.84 & 0.41 \\
\hline & Evennes index $(\mathrm{E})$ & 0.85 & 0.74 & 0.76 & 0.59 \\
\hline & Dominance index (D) & 0.49 & 0.70 & 0.64 & 0.86 \\
\hline \multirow[t]{4}{*}{57 DAT } & $\begin{array}{l}\text { Abundance of aquatic insect species }(\mathrm{N}) \\
\text { (individual } 4 \mathrm{~m}^{-2} \text { ) }\end{array}$ & 14.00 & 13.33 & 18.67 & 0,66 \\
\hline & Shanon wiener index $\left(\mathrm{H}^{\prime}\right)$ & 1.27 & 1.00 & 0.70 & 0.69 \\
\hline & Evennes index $(\mathrm{E})$ & 0.92 & 0.91 & 0.50 & 1.00 \\
\hline & Dominance index (D) & 0.45 & 0.53 & 0.79 & 0.50 \\
\hline \multirow[t]{4}{*}{ Total } & $\begin{array}{l}\text { Abundance of aquatic insect species }(\mathrm{N}) \\
\text { (individual } 4 \mathrm{~m}^{-2} \text { ) }\end{array}$ & 46,00 & 46.33 & 56.33 & 5.33 \\
\hline & Shanon wiener index $\left(\mathrm{H}^{\prime}\right)$ & 1.14 & 1,12 & 1,17 & 1,34 \\
\hline & Evennes index $(\mathrm{E})$ & 0,64 & 0,63 & 0,60 & 0.83 \\
\hline & Dominance index (D) & 0,66 & 0,65 & 0,67 & 0,38 \\
\hline
\end{tabular}

Abundance and species diversity of aquatic insect are increasing along with the increasing age of rice in the plots treated with mycoinsecticides. The more complex the structure of plants are, the more complex the species of insects associated with the plants (Settle et al. 1996) and the more abundant and diverse insect pests in the rice canopy with increasing age of rice plants (Prabawati et al. 2019). The abundance of pests in rice are prey for aquatic insects (Cheong 2009)

The diversity of aquatic insect species in plots applied with abamectin was lower than those applied with the mycoinsecticides. Three species were not found in the abamectin plots (unidentified species of Dytiscidae, Micronecta sp., and unidentified species of Veliidae). This could be due to the broad spectrum of abamectin that can kill various insect species (Luo et al. 2013) including the aquatic insects (Thongphak and Iwai 2016) in this study. These, three species were susceptible to abamectin. The Micronecta sp. is generally found in a healthy aquatic ecosystem. The decreasing number of species or diversity of aquatic insect species in the rice fields could be an indicator of decreasing water quality of the rice fields (Salmah et al. 2017).

It can be concluded that all eight aquatic insect species obtained in this study were predators of rice insect pests. The eight aquatic insect species were: unidentified species of Dytiscidae, Micronecta sp., Mesovelia sp., Ranatra sp., Anisops sp., Microvelia sp., unidentified species of Veliidae, and Orthetrum sp. belong to 7 families (Dytiscidae, Corixidae, Mesoveliidae, Nepidae,
Notonectidae, Veliidae, and Libellulidae), and three orders (Coleoptera, Hemiptera, and Odonata). The application of mycoinsecticides from B. bassiana s.l., M. anisopliae s.l. and $C$. militaris s.l. did not reduce the abundance and species diversity of the aquatic predatory insects, while the application of abamectin reduces the abundance and species diversity of the predatory insects. The application of mycoinsecticides from B. bassiana s.l., M. anisopliae s.l. and $C$. militaris s.l. is a safe application for the aquatic predatory insects, and to control rice insect pests than that of abamectin applications.

\section{ACKNOWLEDGEMENTS}

This research was funded by the Competency-Based Research (PBK) for the 2018 fiscal year based on the Letter of Director of Research and Community Service, Directorate of Research and Community Service (DRPM), Directorate General of Research and Development Strengthening, Ministry of Research, Technology and Higher Education, Number: 0045/E3/LL/2018, January 16, 2018.

\section{REFERENCES}

Ayudya DR, Herlinda S, Suwandi S. 2019. Insecticidal activity of culture filtrates from liquid medium of Beauveria bassiana isolates from 
South Sumatra (Indonesia) wetland soil against larvae of Spodoptera litura. Biodiversitas 20: 2101-2109. DOI: 10.13057/biodiv/d200802

Azod F, Shahidi-Noghabi S, Mahdian K, Smagghe G. 2016. Lethal and sublethal effects of spirotetramat and abamectin on predatory beetles (Menochilus sexmaculatus) via prey (Agonoscena pistaciae) exposure, important for integrated pest management in pistachio orchards. Belgian J Zool 146: 113-122.

Basu S, Subramanian KA, Saha GK. 2016. Aquatic and Semi-aquatic Heteroptera (Insecta: Hemiptera ) of Terai-Dooars Region of West Bengal, India. Halteres 7: 120-135. DOI: 10.5281/zenodo.61516

Dunbar MJ, Warren M, Extence C, Baker L, Cadman D, Mould DJ, Hall J, Chadd R. 2010. Interaction between macroinvertebrates, discharge and physical habitat in upland rivers. Aquatic Conservation 20: S31S44. DOI: $10.1002 / \mathrm{aqc} .1089$

Gustianingtyas M, Herlinda S, Suwandi, Suparman, Hamidson H, Hasbi, Setiawan A, Verawaty M, Elfita, Arsi. 2020. Toxicity of entomopathogenic fungal culture filtrate of lowland and highland soil of South Sumatra (Indonesia) against Spodoptera litura larvae. Biodiversitas 21 (5): 1839-1849. DOI: 10.13057/biodiv/d210510

Hanif KI, Herlinda S, Irsan C, Pujiastuti Y, Prabawati G, Hasbi, Karenina T. 2020. The impact of bioinsecticide overdoses of Beauveria bassiana on species diversity and abundance of not targeted arthropods in South Sumatra (Indonesia) freshwater swamp paddy. Biodiversitas 21 (5): 2124-2136. DOI: 10.13057/biodiv/d210541

Heong KL, Aquino GB, Barrion AT. 2009. Arthropod community structures of rice ecosystems in the Philippines. Bulletin of Entomological Research 81: 407-416. DOI: 10.1017/S0007485300031977

Herlinda S, Rizkie L, Suwandi, Susilawati, Lakitan B, Verawaty M, Hasbi. 2018. Effects of high temperature and ultraviolet-C irradiance on conidial viability and density of Beauveria bassiana and Metarhizium anisopliae isolated from soils of lowland ecosystems in Indonesia. Eurasian J Anal Chem 13: 209-216.

Herlinda S, Yusticia SR, Irsan C, Asmara B, Hadi R. 2019a. Abundance of arthropods inhabiting canopy of rice cultivated using different planting methods and varieties. J Biopest 12: 7-18.

Herlinda S, Karenina T, Irsan C, Pujiastuti Y. 2019b. Arthropods inhabiting flowering non-crop plants and adaptive vegetables planted around paddy fields of freshwater swamps of South Sumatra, Indonesia. Biodiversitas 20: 3328-3339. DOI: 10.13057/biodiv/d201128

Johari A, Herlinda S, Irsan C, Pujiastuti Y. 2016. Phenomenon of Thrips (Thysanoptera) attack on chili plant (Capsicum annuum). Am J Agric Biol Sci 11: 103-109.

Johari A, Herlinda S, Pujiastuti Y, Irsan C, Sartiami D. 2014 Morphological and genetic variation of Thrips parvispinus (Thysanoptera: Thripidae) in chili plantation (Capsicum annuum L .) in the lowland and highland of Jambi Province, Indonesia. Am J Biosci 2: 17-21.

Karenina T, Herlinda S, Irsan C, Pujiastuti Y. 2019. Abundance and species diversity of predatory arthropods inhabiting rice of refuge habitats and synthetic insecticide application in freshwater swamps in South Sumatra, Indonesia. Biodiversitas 20: 2375-2387. DOI: 10.13057/biodiv/d200836

Khan MM, Nawaz M, Hua H, Cai W, Zhao J. 2018. Lethal and sublethal effects of emamectin benzoate on the rove beetle, Paederus fuscipes, a non-target predator of rice brown planthopper, Nilaparvata lugens. Ecotoxicol Environ Saf 165: 19-24. DOI 10.1016/j.ecoenv.2018.08.047

Lakitan B, Alberto A, Lindiana L, Kartika K, Herlinda S, Kurnianingsih, A. 2018a. The benefits of biochar on rice growth and yield in tropical riparian wetland, South Sumatra, Indonesia. Chiang Mai University J Nat Sci 17: 111-126. DOI: 10.12982/CMUJNS.2018.0009

Lakitan B, Hadi B, Herlinda S, Siaga E, Widuri LI, Kartika K, Lindiana L, Yunindyawati Y, Meihana M. 2018b. Recognizing farmers practices and constraints for intensifying rice production at Riparian Wetlands in Indonesia. NJAS-Wageningen J Life Sci 85: 10-20. DOI: 10.1016/j.njas.2018.05.004
Luo L, Sun YJ, Wu YJ. 2013. Abamectin resistance in Drosophila is related to increased expression of P-glycoprotein via the dEGFR and dAkt pathways. Insect Biochem Mol Biol 43: 627-634. DOI: 10.1016/j.ibmb.2013.04.006

Mascarin GM, Jackson MA, Kobori NN, Behle RW, Delalibera JÍ. 2015. Liquid culture fermentation for rapid production of desiccationtolerant blastospores of Beauveria bassiana and Isaria fumosorosea strains. J Invertebr Pathol 127: 11-20.

Margono BA, Bwangoy JRB, Potapov PV, Hansen MC. 2014. Mapping wetlands in Indonesia using Landsat and PALSAR data-sets and derived topographical indices. Geo-Spat Inf Sci 17: 60-71. DOI: 10.1080/10095020.2014.898560

Miller KB, Bergsten J. 2016. Diving beetles of the world: Systematics and biology of the Dytiscidae. Johns Hopkins University Press, Baltimore.

Ohba, Shin-ya. 2009. Feeding habits of the diving beetle larvae, Cybister brevis Aubé (Coleoptera: Dytiscidae) in Japanese wetlands. Appl. Entomol. Zool. 44: 447-453. DOI: 10.1303/aez.2009.447.

Prabawati G, Herlinda S, Pujiastuti Y. 2019. The abundance of canopy arthropods in South Sumatra (Indonesia) freshwater swamp main and ratooned rice applied with bioinsecticides and synthetic insecticide. Biodiversitas 20: 2921-2930. DOI 10.13057/biodiv/d201021.

Safitri A, Herlinda S, Setiawan A. 2018. Entomopathogenic fungi of soils of freshwater swamps, tidal lowlands, peatlands, and highlands of South Sumatra, Indonesia. Biodiversitas 19: 2365-2373. DOI: $10.13057 /$ biodiv/d190647

Salachna A, Olearczyk Z. 2020. Assessment of the ecological potential of the Sola River Cascade on the basis of the selected biological indicators. Journal of Ecological Engineering 21 (1): 81-87. DOI: $10.12911 / 22998993 / 113140$

Salmah MRC, Siregar AZ, Hassan AA, Nasution Z. 2017. Dynamics of aquatic organisms in a rice field ecosystem: effects of seasons and cultivation phases on abundance and predator-prey interactions. Trop Ecol 58: 177-191.

Settle WH, Ariawan H, Astuti ET, Cahyono W, Hakim AL, Hidayana D, Lestari AS, Pajarningsih. 1996. Managing tropical rice pest through concervation of generalist natural enemics and alternative prey. Ecology 77: 1975-1988. DOI: 10.13057/psnmbi/m010334

Shrestha B, Zhang P, Zhang Y, Liu X. 2012. The medicinal fungus Cordyceps militaris: research and development. Mycol Progress 11: 2-17.

Siaga E, Lakitan B, Hasbi H, Bernas SM, Widuri LI, Kartika K. 2019. Floating seedbed for preparing rice seedlings under unpredictable flooding occurrence at tropical riparian wetland. Bulgarian J Agric Sci 25: 326-336.

Sumikarsih E, Herlinda S, Pujiastuti Y. 2019. Conidial density and viability of Beauveria bassiana isolate from Java and Sumatra and their virulence against Nilaparvata lugens at different temperatures. Agrivita 41: 335-349. DOI: 10.17503/agrivita.v41i2.2105

Suwandi, Ammar M, Irsan C. 2012. Application of extract compost increased yield and suppressed the diseases of ratoon rice crop in tidal swamp of Banyuasin Regency. J Lahan Suboptimal 1: 116-122. DOI: 10.33230/JLSO.1.2.2012.15. [Indonesian]

Thirumalai G, Ramakrishna. 2002. A checklist of aquatic and semiaquatic Hemiptera (Insecta) of Rajasthan, India. Rec Zool Surv India 100: 101-110.

Thongphak Duangrat and Chuleemas Boonthai Iwai. 2016. Diversity of Aquatic Insects in the Organic and Conventional Rice Fields in Khon Kaen Thailand. Intl J Environ Rural Dev 7: 57-62.

Wakhid, Rauf A, Krisanti M, Sumertajaya IM, Maryana N. 2020. Species richness and diversity of aquatic insects inhabiting rice fields in Bogor, West Java, Indonesia. Biodiversitas 21: 34-42. DOI: 10.13057/biodiv/d210106

Watanabe, Reiya. 2019. Field observation of predation on a horsehair worm (Gordioida: Chordodidae) by a diving beetle larva Cybister brevis Aubé (Coleoptera: Dytiscidae). Entomol Sci 22: 230-232. DOI: $10.1111 /$ ens. 12356 